\title{
Identifikasi Kompetensi Bidan: Data Riset Pendidikan Tenaga Kesehatan Tahun 2017
}

\author{
Midwife Competency Identification: Health Workforce Education Research \\ Data 2017
}

Sefrina Werni ${ }^{1}$, Rosita ${ }^{1}$, Nita Prihartini ${ }^{1}$, Mieska Despitasari ${ }^{1}$

1) Pusat Penelitian dan Pengembangan Sumber Daya dan Pelayanan Kesehatan, Jalan Percetakan Negara No. 29 Jakarta 10560, Indonesia

Korespondensi: sefrindra@gmail.com

Submitted: 3 September 2019, Revised: 2 Desember 2019, Accepted: 13 Desember 2019

https://doi.org/10.22435/jpppk.v3i3.2458

\begin{abstract}
Abstrak
Bidan sebagai tenaga kesehatan strategis yang berperan dalam pelayanan kesehatan ibu dan anak dituntut memiliki kompetensi tinggi untuk dapat menjalankan fungsinya dengan baik. Kompetensi yang tinggi dapat tercapai bila penyelenggara pendidikan profesi bidan memenuhi standar penyelenggaraan pendidikan. Berdasarkan data Majelis Tenaga Kesehatan Indonesia (MTKI) tahun 2016, nilai rata-rata uji kompetensi DIII kebidanan hanya 41,08 . Peserta uji kompetensi yang belum lulus sebanyak $46,5 \%$. Hasil yang masih jauh dari harapan juga ditunjukkan dari rerata try out uji kompetensi tenaga kesehatan tahun 2012 hingga tahun 2015 yang cenderung menurun. Kajian ini bertujuan untuk mendapatkan informasi identifikasi kompetensi bidan berdasarkan Kepmenkes 369/MENKES/SK/III/2007 tentang standar profesi bidan pada hasil Risdiknakes tahun 2017. Kajian dilakukan menggunakan observasi, wawancara mendalam dan literatur review. Informan adalah bidan di puskesmas dan pakar kebidanan. Hasil kajian menunjukkan bahwa kompetensi bidan di fasilitas pelayanan kesehatan masih belum sesuai standar. Beberapa faktor dalam penyelenggaraan pendidikan kebidanan turut membentuk kompetensi bidan yang dihasilkan. Proses rekrutmen calon peserta didik, kualitas dosen, dan proses penyelenggaraan pendidikan kebidanan secara keseluruhan merupakan komponen yang harus menjadi fokus untuk menghasilkan bidan yang sesuai dengan standar kompetensi seperti tercantum dalam Kepmenkes Nomor 369/MENKES/SK/III/2007.
\end{abstract}

Kata kunci: kompetensi bidan, kajian kebidanan, pendidikan bidan, kurikulum kebidanan

\begin{abstract}
Midwives are strategic health workers who play an important role in maternal and child health services. They are required to have well competencies to run their tasks properly. Well, competencies can be achieved if the midwife's professional education providers meet the standards. Based on the Indonesian Health Workers' Assembly (MTKI) data in 2016, the average value of the DIII midwifery-competency test was only 41.08. Participants who failed the competency test were as much as $46.5 \%$. It is still far from the expectation as the average value of health workers' competency tests try out between 2012 to 2015 tends to decline. This study aims to identify midwife competencies based on Minister of Health's decree No. 369/MENKES/SKJ III/2007 on midwives' profession standards and the results of the 2017 Research on Health Workers'Education (Risdiknakes). The study was conducted using observation, in-depth interviews, and literature review. Informants are midwives at primary health care and midwifery experts. The results of the study indicate that midwife competencies in health care facilities are still not up to standard. Several factors in the administration of midwifery education also shape the competence of the midwives produced. The process of recruiting prospective students, the quality of lecturers, and the process of conducting midwifery education as a whole
\end{abstract}


are components that must be the focus to produce midwives that comply with the competency standards in Minister of Health's decree No. 369/MENKES/SK/III/ 2007.

Keywords: midwife competencies, midwifery studies, midwife education

\section{Pendahuluan}

Tenaga kesehatan menurut UndangUndang Nomor 36 tahun 2014 adalah orang yang mengabdikan diri di bidang kesehatan dan memiliki pengetahuan dan/atau keterampilan melalui pendidikan di bidang kesehatan yang untuk jenis tertentu memerlukan kewenangan dalam melakukan upaya kesehatan. ${ }^{1}$ Bidan merupakan tenaga kesehatan strategis yang banyak berperan dalam pelayanan kesehatan ibu dan anak. Bidan dituntut memiliki kompetensi yang baik sehingga dapat menjalankan fungsinya dengan optimal. Untuk memperoleh bidan dengan kompetensi sesuai harapan, maka penyelenggara pendidikan profesi kebidanan tentunya juga harus memenuhi standar penyelenggaraan pendidikan.

Uji Kompetensi ditujukan untuk mencapai standar kompetensi lulusan yang memenuhi standar kompetensi kerja. Saat ini, banyak lulusan baru tenaga kesehatan masih belum memiliki kompetensi sesuai standar. Pendidikan DIII kebidanan merupakan salah satu pendidikan vokasi yang telah melaksanakan uji kompetensi bagi lulusannya. Berdasarkan data Majelis Tenaga Kesehatan Indonesia (MTKI) pada tahun 2016, nilai rata-rata uji kompetensi DIII kebidanan hanya 41,08. Peserta uji kompetensi yang belum lulus sebanyak $46,5 \%$. Hasil yang masih jauh dari harapan juga ditunjukkan dari rerata try out uji kompetensi tenaga kesehatan tahun 2012 hingga tahun 2015 yang cenderung menurun.

Laporan hasil evaluasi penyelenggaraan pendidikan DIII kebidanan di 5 provinsi wilayah binaan Global Alliance Vaccines and Immunization (GAVI) menyatakan dengan menggunakan pendekatan sistem, terdapat perbedaan baik pada input, proses, maupun output antar institusi pendidikan DIII kebidanan menurut wilayah maupun kepemilikan institusi. Juga terdapat perbedaan pengetahuan dan keterampilan mahasiswa menurut wilayah dan provinsi. ${ }^{2}$ Hasil Riset Pendidikan Tenaga Kesehatan (Risdiknakes) 2017 menunjukkan bahwa penyelenggaraan pendidikan di institusi pendidikan
DIII kebidanan, belum memenuhi standar yang telah ditetapkan baik dari sisi input, proses maupun output. Komponen input pada Risdiknakes terdiri dari proses rekrutmen mahasiswa, sumber daya manusia, dan sarana prasarana. Proses meliputi implementasi kurikulum, proses pembelajaran, dan suasana akademik, sementara output berupa tingkat pengetahuan mahasiswa. ${ }^{3}$

Kurikulum dirumuskan sebagai keseluruhan program yang direncanakan, disusun, dilaksanakan, dan dievaluasi, serta dikembangkan oleh suatu program studi, dalam rangka menghasilkan lulusan yang memiliki capaian pembelajaran tertentu yang direncanakan. ${ }^{4}$ Kurikulum Pendidikan Tinggi dikembangkan oleh setiap Perguruan Tinggi dengan mengacu pada Standar Nasional Pendidikan Tinggi untuk setiap Program Studi yang mencakup pengembangan kecerdasan intelektual, akhlak mulia, dan keterampilan. Standar Nasional Pendidikan adalah kriteria minimal tentang pembelajaran pada jenjang pendidikan tinggi di perguruan tinggi di seluruh wilayah Indonesia yang terdiri atas standar kompetensi lulusan, isi pembelajaran, proses pembelajaran, penilaian pembelajaran, dosen dan tenaga kependidikan, sarana dan prasarana pembelajaran, pengelolaan pembelajaran, dan standar pembiayaan pembelajaran. ${ }^{5}$ Kurangnya mutu tenaga kesehatan merupakan salah satu permasalahan tenaga kesehatan di Indonesia yang berdampak pada rendahnya akses masyarakat terhadap pelayanan kesehatan yang berkualitas. Bidan merupakan tenaga kesehatan strategis yang erat kaitannya dengan berbagai pelayanan kesehatan khususnya di pelayanan kesehatan ibu dan anak. Pelayanan yang diberikan oleh bidan harus sesuai dengan kompetensi yang telah tercantum di Kepmenkes tentang standar profesi bidan. Kajian ini dilakukan untuk mendapatkan informasi implementasi kompetensi bidan berdasarkan Kepmenkes 369/Menkes/SK/III/2007 tentang standar profesi bidan berdasarkan hasil Risdiknakes tahun 2017. 


\section{Bahan dan Metode}

Metode kajian menggunakan observasi dan wawancara mendalam dilengkapi dengan literatur review. Waktu kajian selama 11 bulan (FebruariDesember 2018) di wilayah DKI Jakarta dan Jawa Barat. Informan adalah 2 orang lulusan yang berasal dari institusi pendidikan DIII kebidanan pemerintah dan non-pemerintah. Informan tambahan terdiri dari atasan dan rekan kerja lulusan yang terpilih sebagai sampel, serta pakar yaitu Pengurus Pusat Asosiasi Pendidikan Diploma Kebidanan (AIPKIND), pengurus Ikatan Bidan Indonesia (IBI), Direktorat Jenderal Pembelajaran dan Kemahasiswaan Kementerian Riset, Teknologi, dan Pendidikan Tinggi (Ditjen Belmawa Kemenristekdikti), dan Pusat Pendidikan Badan Pengembangan dan Pendayaan Sumber Daya Manusia Kesehatan (Pusdik BPPSDMK). Instrumen terdiri dari panduan wawancara mendalam dan daftar tilik observasi pelayanan yang dilakukan lulusan dengan mengacu pada standar kompetensi bidan berdasarkan Kepmenkes RI Nomor 369/MENKES/SK/III/2017. Tahapan pelaksanaan kegiatan kajian meliputi konfirmasi lapangan dan diskusi dengan pakar dan stakeholder. Konfirmasi lapangan dilakukan melalui observasi terhadap lulusan pada saat melaksanakan pelayanan serta wawancara mendalam terhadap lulusan, atasan dan rekan kerja lulusan terpilih. Observasi dilakukan di ruang periksa tertutup di fasyankes tempat lulusan bekerja oleh pihak yang kompeten yaitu pengurus IBI. Dalam ruangan tersebut hanya ada lulusan sebagai responden, pasien, dan observer dari IBI. Dengan demikian, kerahasiaan dan kenyamanan lulusan serta pasien terjaga. Analisa data hasil wawancara mendalam dilakukan dengan content analysis melalui tahapan pembuatan transkrip, matriks, dan penyajian hasil. Data hasil observasi pelayanan selanjutnya diidentifikasi dan dibandingkan dengan standar kompetensi bidan. Data hasil literatur review di sajikan secara deskriptif

\section{Hasil}

Hasil uji kompetensi bidan lulusan pendidikan DIII kebidanan diperoleh dari web uji kompetensi bidan yang didownload pada tahun $2018^{6}$ dan hasil konfirmasi lapangan serta informasi dari pakar.

\section{Hasil Uji Kompetensi}

Bidan harus memenuhi kompetensi bidan melalui uji kompetensi. Uji kompetensi merupakan sarana untuk menyaring standar kompetensi. Uji kompetensi diberlakukan sejak tahun 2014. Bentuk uji kompetensi berupa bagaimana cara menangani kasus, bagaimana manajemennya. ${ }^{7}$ Kementerian Kesehatan sebagai pembina institusi pendidikan kesehatan menyampaikan bahwa hasil uji kompetensi lulusan ini sangat bervariasi, ada yang nilainya sangat tinggi, ada pula yang sangat rendah. Risdiknakes 2017 melakukan penilaian uji tingkat pengetahuan terhadap mahasiswa tingkat akhir DIII kebidanan. Uji pengetahuan mengacu pada standar soal uji kompetensi. Hasil penilaian menunjukkan bahwa rata-rata nilai sebesar 46,8 dengan nilai tertinggi 72,0 dan terendah $8,0 .^{3}$ Tingkat kelulusan bidan yang mengikuti uji kompetensi untuk pertama kali (first taker) masih di bawah 50 persen. ${ }^{7}$ Gambar 1 menunjukkan trend kelulusan uji kompetensi bidan dari tahun 2015 hingga 2018. Dari Gambar 1 terlihat bahwa jumlah bidan yang lulus uji kompetensi cenderung turun. ${ }^{6}$

Berdasarkan hasil wawancara dengan Pusat Pendidikan Pengembangan dan Pendayaan Sumber Daya Manusia Kesehatan dan Ikatan Bidan Indonesia menyatakan bahwa pada tingkat kelulusan pada masing-masing angkatan berbedabeda, ada yang mencapai 99 persen dan ada yang masih di bawah 50 persen. Bagi peserta yang tidak lulus uji kompetensi harus mengikuti sampai lulus, kondisi ini menjadikan beberapa lulusan harus mengulang sampai berkali-kali karena saat ini untuk pelaksanaan uji kompetensi belum diterapkan sistem exit exam.

“...yang ukomnya bagus yang 99,73\% ..., tapi ada juga ...24,74\% ... seharusnya DIKTI yang membina karena di bawah DIKTI ya.... tahun depan itu sudah harus semua memang exit exam" (BPPSDMK)

“... sampai sekarang belum ada batasnya, ada yang udah 7 kali nggak lulus ..." (IBI)

“...jadi kan di aturannya kan exit exam cuman dikti belum memutuskan exit exam semoga 2019 bisa exit exam..." (IBI) 


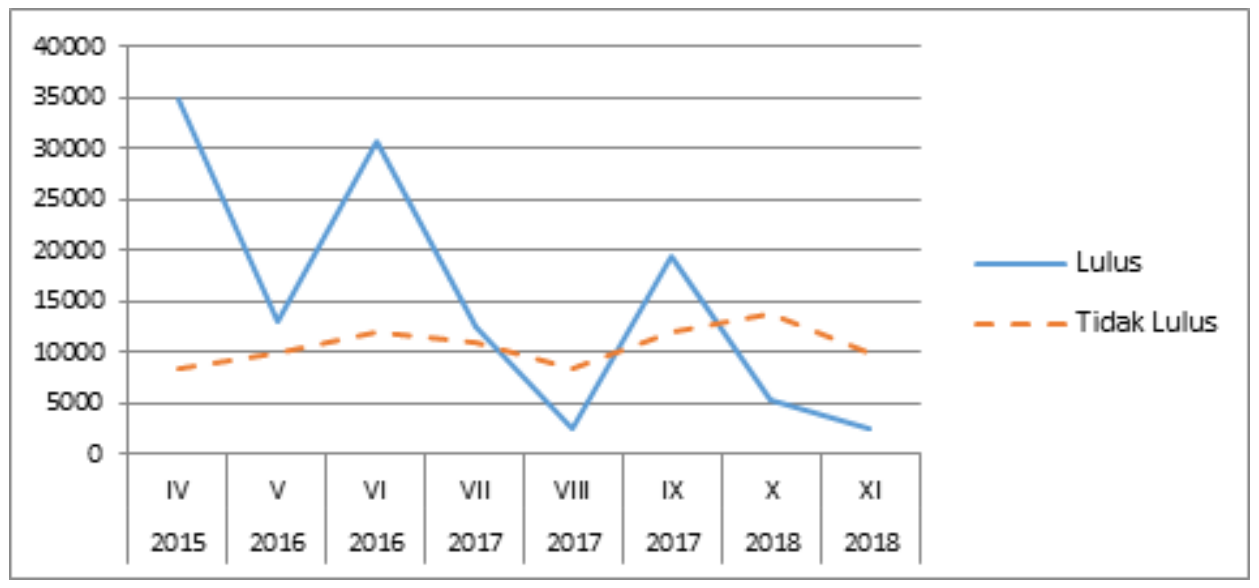

(sumber http://ukbidan.ristekdikti.go.id/index.php/pages/statistik_lulus) ${ }^{6}$

\section{Gambar 1. Peserta Lulus dan Tidak Lulus Uji Kompetensi dari Tahun 2015-2018}

Exit exam menjadi salah satu alternatif solusi, tetapi sampai saat ini Kemenristekdikti belum memberlakukan sistem tersebut. Padahal dengan exit exam, kualitas lebih terjamin karena apabila seorang mahasiswi tidak lulus uji kompetensi maka mahasiswi tersebut tidak dapat diluluskan dari pendidikan.

Lulusan DIII kebidanan yang belum lulus uji kompetensi seharusnya masih menjadi tanggung jawab institusi pendidikan. Untuk itu setiap institusi pendidikan harus mempunyai sistem mutu. Selain Institusi, Kemenkes dan Kemenristekdikti harus ikut membina lulusan yang belum lulus uji kompetensi. Sesuai dengan hasil wawancara dengan Asosiasi Pendidikan Diploma Kebidanan dan Ikatan Bidan Indonesia berikut ini.

“...setiap institusi harus punya sistem mutu, diwajibkan akhir 2017 sudah punya sistem mutu, mengacu pada kurikulum" (AIPKIND)

“... kita tidak sejauh itu, kita tidak punya kewenangan sejauh itu. Itu nanti pembinaan perguruan tinggi itu ada di dikti nah di bawah lingkup kemenkes ada di bawah PPSDM ..." (IBI)

\section{Identifikasi kompetensi berdasarkan observasi}

Kompetensi bidan adalah kemampuan bidan untuk mengerjakan suatu tugas dan pekerjaan yang dilandasi oleh pengetahuan, keterampilan, dan sikap kerja. Standar kompetensi bidan adalah rumusan suatu kemampuan bidan yang dilandasi oleh pengetahuan, keterampilan, dan sikap. Kementerian kesehatan menetapkan bidan harus memiliki sembilan kompetensi berdasarkan Kepmenkes RI Nomor 369/MENKES/SK/III/2007 tentang standar profesi bidan. ${ }^{8}$ Tabel 1 menyajikan identifikasi kesenjangan kompetensi bidan berdasarkan observasi terhadap 2 orang lulusan bidan yang bekerja di fasilitas pelayanan kesehatan.

Bidan dituntut memiliki tanggung jawab dan kompetensi yang tinggi tetapi kondisi ini belum sejalan dengan mutu pendidikan kebidanan itu sendiri. Kompetensi bidan dibentuk dari masa pendidikan kebidanan. Menurut pengurus IBI, seharusnya uji kompetensi tidak menjadi masalah karena soal sudah disusun berdasarkan kurikulum. Kurikulum sebagai pedoman penyelenggaraan pendidikan kebidanan disusun untuk dapat menghasilkan bidan yang memiliki kompetensi tinggi sehingga mampu menjawab kebutuhan akan pelayanan kesehatan ibu dan anak yang optimal. Kurikulum disusun oleh institusi perguruan tinggi berdasarkan pedoman yang telah ditetapkan DIKTI sehingga kurikulum sudah sesuai dengan kompetensi yang diharapkan. Namun, adanya otonomi yang diberikan terhadap institusi perguruan tinggi menyebabkan implementasi kurang sesuai dengan yang telah ditentukan. 
Tabel 1. Hasil Konfirmasi Lapangan Berdasarkan Kompetensi Profesi Bidan yang Tercantum dalam Kepmenkes RI Nomor 369/MENKES/SK/III/2007

\section{Kompetensi Profesi Bidan yang Tercantum dalam Kepmenkes RI Nomor 369/MENKES/ SK/III/2007}

Observasi

- Bidan kurang mengetahui kebudayaan dasar masyarakat, praktik kesehatan tradisional, fasyankes tempat merujuk, angka kesakitan dan kematian bayi, advokasi hak wanita, kesehatan lingkugan serta standar profesi dan praktik bidan.

- bidan kurang mengetahui hal-hal terkait epidemiologi.

- Bidan kurang mengetahui masalah seksualitas, anatomi fisiologi reproduksi, norma-budaya seksualitas, keluarga berencana secara tradisional, tablet vagina, tisu vagina, kelangsungan hidup anak, indikator penyakit akut dan kronis, dan Kekerasan Dalam Rumah Tangga (KDRT)

- Bidan kurang terampil dalam melakukan pemeriksaan hemoglobin, protein, glukosa bahkan kadang kadang tidak tahu cara menyimpulkan hasil pemeriksaan.

- Bidan tidak pernah melakukan pemasangan Alat Kontrasepsi Dalam Rahim (AKDR), hanya sesekali melakukan pencabutan AKDR.

Kompetensi 3: Bidan memberi asuhan antenatal bermutu tinggi untuk mengoptimalkan kesehatan selama kehamilan yang meliputi: deteksi dini, pengobatan atau rujukan dari komplikasi tertentu

Kompetensi 4: Bidan memberikan asuhan yang bermutu tinggi, tanggap terhadap kebudayaan setempat selama persalinan, memimpin selama persalinan yang bersih dan aman, menangani situasi kegawatdaruratan tertentu untuk mengoptimalkan kesehatan wanita dan bayinya yang baru lahir.
- Pengetahuan terhadap anatomi fisiologi manusia juga masih kurang. Masih belum memahami tentang perlunya mengetahui cara penularan toxo. Keterampilan dasar yang belum dikuasai antara lain tidak pernah ukur pelvic, menilai tulang panggul, kurang bisa menilai dengan fetoskop, belum pernah menangani preeklampsi ringan, abortus iminen, Pengetahuan tambahan yang belum dikuasai antara lain resusitasi jantung paru, tanda gejala indikasi asthma, kelainan jantung, dan serotinus.

- Bidan kurang paham dengan resusitasi jantung paru, tanda gejala indikasi asthma.

- Bidan kurang paham cara identifikasi tumbuh janin yang tidak adekuat, Small for Gestational Age (SGA), dan Large for Gestational Age (LGA).

- Bidan kurang mengetahui masalah preeklampsi berat dan hipertensi, tidak pernah menangani rujuk kematian janin, kurang dapat menangani edema, sakit kepala hebat, nyeri epigastrum akibat hipertensi, gangguan pandangan, dan diabetes mellitus. - Bidan tidak pernah menangani polyhidramnion, kelainan kongenital, infeksi menular seksual (IMS), vaginitis, infeksi saluran kemih (ISK) bumil, dan infeksi saluran nafas ibu hamil. Tidak dilakukan assessment komponen riwayat kesehatan, nilai normal bakteri dalam urin, 


\section{Kompetensi Profesi Bidan yang Tercantum dalam Kepmenkes RI Nomor 369/MENKES/ SK/III/2007}

Kompetensi 5: Bidan memberikan asuhan pada ibu nifas dan menyusui yang bermutu tinggi dan tanggap terhadap budaya setempat.

Kompetensi 6: Bidan memberikan asuhan yang bermutu tinggi, komprehensif pada bayi baru lahir sehat sampai dengan 1 bulan.

Kompetensi 7: Bidan memberikan asuhan yang bermutu tinggi, komprehensif pada bayi dan balita sehat (1 bulan -5 tahun).

Kompetensi 8: Bidan memberikan asuhan yang bermutu tinggi dan komprehensif pada keluarga, kelompok dan masyarakat sesuai dengan budaya setempat.

Kompetensi 9: Melaksanakan asuhan kebidanan pada wanita/ibu dengan gangguan sistem reproduksi.

\section{Observasi}

- Tidak diketahui bidan antara lain hematoma vulva, incontinentia alvi. bidan kurang mengetahui mengenai anemia kronis, retensi urin, asuhan dan konseling abortus, dan gelaja komplikasi abortus.

Tidak dilakukan assessment

Tidak dilakukan assessment

- Pengetahuan tambahan yang tidak dikuasai bidan antara lain mengenai kepemimpinan untuk semua, pemasaran sosial, peran serta masyarakat, dan Audit Maternal Perinatal (AMP).

- Keterampilan dasar yang belum dikuasai antara lain menolong ibu bersalin dan mengelola polindes.

- Pengetahuan dasar yang tidak diketahui adalah mengenai gejala ISK.

- Keterampilan dasar yang belum dikuasai antara lain mengidentifikasi gangguan dan kelainan sistem reproduksi, keputihan, perdarahan tidak teratur, mengobati abortus spontan, menggunakan mikroskop untuk identifikasi kelainan sel atau mikroba penyebab gangguan reproduksi, dan melakukan hapusan vagina.
“... sebetulnya di kurikulum itu sudah, capaian capaian kompetensi itu sudah sesuai dengan apa yang kita harapkan hanya di dalam implementasinya dunia pendidikan kita ini sistemnya kan otonomi institusi pendidikan DIII memang besar" (IBI)

Masalah adanya tuntutan indeks prestasi kumulatif (IPK) tinggi untuk bekerja di fasilitas pelayanan kesehatan atau suatu instansi menyebabkan institusi pendidikan memberikan kesempatan remedial atau memberikan tugas tertentu untuk menaikkan IPK. Permenristekdikti Nomor 44 tahun 2015 menyebutkan bahwa mahasiswa berprestasi akademik tinggi merupakan mahasiswa yang mempunyai Indeks Prestasi Semester (IPS) lebih besar dari 3,00 (tiga koma nol nol) dan memenuhi etika akademik. ${ }^{5}$ Hasil Risdiknakes 2017 juga menunjukkan rerata nilai IPK mahasiswa tinggi namun rerata hasil uji tingkat pengetahuannya cenderung rendah. Penjelasan mengenai hal tersebut diperoleh dari prodi bahwa beberapa prodi menerapkan standar minimal IP/IPK di atas 2,75 karena mengikuti tuntutan pasar. Klien/ lapangan kerja hanya menerima mahasiswa dengan IPK tinggi, termasuk juga standar minimal IPK untuk seleksi calon pegawai negeri sipil. ${ }^{3}$

Selain dari proses pendidikan, kualitas calon peserta didik pada saat rekrutmen pun turut menentukan kompetensi bidan yang dihasilkan. Beberapa institusi pendidikan kebidanan tidak membatasi jumlah peserta yang mendaftar saat rekrutmen, ${ }^{3}$ seperti pernyataan dari AIPKIND berikut.

“... di input, kualitas saringan masuk juga rendah, pemilik sekolah atau yayasan berkuasa juga untuk penerimaan, tidak bisa diatur, meraup sebanyak banyaknya keuntungan " (AIPKIND)

Dosen dan sarana prasarana menjadi faktor yang akan memengaruhi kualitas lulusan yang dihasilkan. Banyak dosen yang belum sesuai dengan standar, diantaranya jenjang pendidikan dosen yang seharusnya berpendidikan S2 kebidanan, tetapi saat ini masih bervariasi. Di institusi pendidikan 
kebidanan masih banyak ditemukan dosen dengan kualifikasi S2 Kesehatan Masyarakat atau Master Pendidikan yang tidak paham tentang pertolongan persalinan. Sarana praktik juga belum sesuai dengan kebutuhan, sehingga kemampuan atau keterampilan mahasiswi sulit berkembang. Hal tersebut diperkuat pernyataan AIPKIND bahwa dosen dari segi jumlah dan kualitas masih kurang. Hasil wawancara mendalam dengan pengurus IBI Pusat dapat disimpulkan bahwa ketersediaan sarana praktik tidak sesuai dengan jumlah mahasiswi (lahan praktek untuk mahasiswi sangat kurang)

“... dosen dari sisi jumlah dan kualifikasi memengaruhi proses, bukan hanya ijazah tapi juga pengalaman praktek. Tiap ibu responnya berbeda beda tiap mau bersalin, jadi pengalaman praktek itu penting sebagai dosen" (AIPKIND)

“...: iya lahan praktek yang sesuai dengan mahasiswanya dan menerima mahasiswa itu harus ada batasannya ya disesuaikan dengan jumlah dosen nya, disesuaikan dengan lahan prakteknya jumlah kasusnya supaya mereka mendapat kesempatan untuk bisa praktek" (IBI)

Kebijakan pendayagunaan tenaga bidan belum sesuai harapan. Di sisi lain banyak daerah yang membutuhkan bidan, dan masih terjadi ketimpangan distribusi tenaga bidan khususnya di wilayah timur Indonesia. Kemeristekdikti merekomendasikan percepatan merger institusi pendidikan yang mahasiswinya kurang dari 100 .

"Tidak kami tidak batasi kami menerima sebanyak-banyak nya itu kan untuk umum" (INSTITUSI)

“.... student body di bawah 1000 net 2019 harus sudah merger" (KEMENRISTEKDIKTI)

Untuk menjaga kualitas lulusan melalui pengembangan mutu pendidikan kebidanan, pemerintah melakukan berbagai program seperti pendidikan jarak jauh untuk tenaga bidan dan perawat dan diberlakukannya skema detasharing dosen kebidanan. Hal ini sesuai dengan pernyataan dari bagian pusat pendidikan BPPSDMK.
“... Kalau kami bu memetakan di bagian pengembangan memetakan itu kita sudah jalan dengan skema deta sharing artinya dosen dosen yang akreditasinya bagus yang $B$, yang A, kita turunkan ke akreditasi yang $C$ semacam pembinaan tadi, ..." (BPPSDMK)

\section{Pembahasan}

Kompetensi bidan adalah kemampuan yang dimiliki oleh bidan yang meliputi pengetahuan, keterampilan, dan sikap untuk memberikan pelayanan kebidanan. Uji kompetensi adalah proses pengukuran pengetahuan, keterampilan, dan perilaku peserta didik pada perguruan tinggi yang menyelenggarakan program studi Kebidanan. ${ }^{9}$ Berdasarkan Surat Edaran DIKTI No. 704/e.e3/ dt/2013 yang dikeluarkan pada 24 Juli 2013, lulusan pendidikan DIII Kebidanan dan Keperawatan diharuskan mengikuti uji kompetensi di akhir proses pendidikan sebagai exit exam. ${ }^{10}$ Namun saat ini, uji kompetensi masih dilaksanakan setelah kelulusan. Hasil penelitian Rahmah Fitria, dkk. tahun 2019 menyatakan bahwa uji kompetensi dilakukan sebelum lulus disetujui oleh kementerian, organisasi profesi, institusi, dosen pendidik, AIPKIND, dan panitia nasional dengan alasan siswa retaker menjadi tanggung jawab institusi karena berkaitan dengan pembinaan untuk uji kompetensi, namun calon peserta/mahasiswa tidak menyetujui hal tersebut. ${ }^{11}$ Dari periode IV/2015 sampai periode $\mathrm{XI} / 2018$, grafik tingkat kelulusan uji kompetensi bidan di Indonesia menunjukkan terjadinya penurunan jumlah lulusan artinya adalah sudah harus diberlakukan penjaminan mutu dengan uji kompetensi yang bersifat exit exam.

Hasil observasi pada dua orang bidan menunjukkan bahwa kompetensi bidan yang diobservasi tidak sesuai dengan standar kompetensi. Kompetensi yang masih kurang antara lain beberapa poin kompetensi 1 yaitu kurang tahu beberapa hal seperti kebudayaan dasar masyarakat, praktik kesehatan tradisional, fasyankes tempat merujuk, angka kesakitan dan kematian bayi, advokasi hak wanita, kesehatan lingkugan, epidemiologi. Kompetensi lainnya yang belum sesuai meliputi beberapa poin kompetensi 2 (pra konsepi, KB dan ginekologi), kompetensi 3 (asuhan dan konseling selama kehamilan), kompetensi 5 (asuhan ibu nifas 
dan menyusui), kompetensi 8 (kebidanan komunitas) dan kompetensi 9 (asuhan pada ibu nifas/wanita dengan gangguan reproduksi). Kondisi ini sesuai dengan hasil penelitian Yeyen Putriana pada tahun 2012 yang menunjukkan bahwa pengetahuan mata kuliah Asuhan Kebidanan 5 dan Ilmu Kesehatan Masyarakat mempunyai relevansi yang sangat rendah dengan kemampuan bidan melaksanakan upaya perawatan kesehatan masyarakat (Perkesmas) di daerah pedesaan; keterampilan Asuhan Kebidanan 5 mempunyai relevansi yang sangat rendah dengan kemampuan bidan dalam melaksanakan upaya Perkesmas di daerah pedesaan; sikap bidan terhadap program Perkesmas mempunyai relevansi yang kuat terhadap kemampuan bidan dalam melaksanakan upaya Perkesmas di daerah pedesaan, dan secara bersama-sama antara kompetensi Asuhan Kebidanan Komunitas dan Ilmu Kesehatan Masyarakat memiliki relevansi yang sangat kuat dengan kemampuan bidan dalam melaksanakan upaya Perkesmas di daerah pedesaan. ${ }^{12}$

Hasil penelitian Despitasari dan Rosita pada tahun 2013 menunjukkan hal yang sama di mana kompetensi kebidanan komunitas masih rendah. Hasil penelitian tersebut juga menyimpulkan bahwa semakin tinggi kompetensi bidan, semakin tinggi pula pelaksanaan wewenangnya dalam praktik asuhan kebidanan. ${ }^{13}$

Kompetensi bidan tidak dapat tercapai secara optimal akibat banyaknya kendala di institusi pendidikan DIII Kebidanan antara lain implementasi kurikulum yang belum diterapkan, tuntutan IPK yang tinggi, jumlah dan kualitas dosen, serta sarana dan prasarana terutama fasilitas laboratorium yang tidak memadai, tempat praktik yang terbatas tidak sebanding dengan jumlah mahasiswi. ${ }^{7}$ Hasil penelitian Ronald Hutapea pada tahun 2011 menunjukkan adanya hubungan bermakna antara kinerja bidan dengan semua aspek dalam sistem pendidikannya. Analisis statistik menunjukkan adanya korelasi yang nyata antara kinerja bidan di tempat kerja dengan beberapa variabel antara lain sistem rekrutmen, latar belakang sekolah, dan motivasi. ${ }^{14}$ Artikel hasil penelitian Ronald Hutapea menyimpulkan bahwa sistem pendidikan bidan dewasa ini telah cukup efektif dalam menghasilkan bidan-bidan yang kompeten dan termotivasi. ${ }^{14}$ Sedangkan hasil penelitian
Risdiknakes 2017 menunjukkan adanya kesenjangan atau ketidakselarasan antara IPK lulusan DIII Kebidanan dengan hasil uji kompetensi bidan.

Rendahnya kelulusan uji kompetensi dan ketidaksesuaian antara IPK rata-rata kelulusan dengan hasil uji kompetensi dapat disebabkan oleh faktor diri mahasiswi itu sendiri. Tenaga dosen yang tidak memenuhi kualifikasi seperti dosen dengan pendidikan S2 yang bukan bidang kebidanan misalnya S2 Kesehatan Masyarakat yang tidak paham tentang pertolongan persalinan juga menjadi salah satu faktor. Selain itu, rasio dosen dengan mahasiswi yang tidak ideal menyebabkan lulusan DIII Kebidanan menjadi kurang berkualitas, tidak memiliki kompetensi yang diharapkan padahal dosen memegang peranan penting untuk menghasilkan lulusan yang berkualitas dan memenuhi kompetensi yang diharapkan. ${ }^{15}$ Sarana dan prasarana seperti sarana praktikum yang kurang baik dalam jumlah dan kualitas turut berperan dalam rendahnya kompetensi bidan. Hasil penelitian Hadina dkk. menyimpulkan bahwa rendahnya hasil kelulusan mahasiswa pada uji kompetensi bidan dipengaruhi oleh rendahnya motivasi dan minat belajar mahasiswi, ketidakjujuran dalam membuat laporan dan belum ada bimbingan belajar khusus menghadapi uji kompetensi.

Berdasarkan hasil eksplorasi diperoleh informasi bahwa faktor yang bersumber dari diri mahasiswimerupakanfaktorpalingdominanterhadap keberhasilan seseorang pada uji kompetensi. Faktor yang memengaruhi kelulusan mahasiswi pada uji kompetensi meliputi minat, motivasi, kepercayaan diri, kejujuran, dan ketelitian. Hasil analisis rasch model menunjukkan bahwa minat belajar mahasiswi pada institusi pendidikan yang dijadikan sampel sangat rendah. Sikap dosen yang baik terhadap mahasiswi memainkan peran untuk meningkatkan partisipasi mahasiswi dalam kelas. Motivasi belajar merupakan pendorong yang menggerakkan mahasiswi untuk mengikuti proses pembelajaran dengan baik. Hasil eksplorasi mendapatkan bahwa mahasiswi yang kurang termotivasi belajar tidak memperoleh target kompetensi sesuai yang dipersyaratkan oleh pendidikan. Dilain pihak, institusi pendidikan kebidanan memang belum memfasilitasi pembelajaran khusus persiapan uji kompetensi. ${ }^{16}$ 


\section{Kesimpulan}

Kompetensi bidan di fasilitas pelayanan kesehatan masih belum sesuai standar. Beberapa faktor dalam penyelenggaraan pendidikan kebidanan turut membentuk kompetensi bidan yang dihasilkan. Proses rekrutmen calon peserta didik, kualitas dosen, dan proses penyelenggaraan pendidikan kebidanan secara keseluruhan merupakan komponen yang harus menjadi fokus untuk menghasilkan bidan yang sesuai dengan standar kompetensi seperti tercantum dalam Kepmenkes Nomor 369/MENKES/SK/ III/2007.

Implementasi kurikulum belum diterapkan secara optimal akibat banyaknya kendala di institusi pendidikan DIII kebidanan. Ketidaksesuaian ini pada prinsipnya dapat dibagi menjadi dua hal. Hal pertama adalah kurikulum yang belum sepenuhnya sesuai dengan kompetensi bidan seperti yang dipersyaratkan dalam Kepmenkes RI Nomor 369/MENKES/SK/III/2007. Hal kedua yaitu implementasi kurikulum yang belum sepenuhnya dilaksanakan oleh institusi pendidikan DIII kebidanan.

\section{Saran}

Perlu dilakukan pembinaan dan evaluasi terhadap institusi pendidikan kebidanan sebagai penyelenggaraan proses pembelajaran. Pembinaan dan evaluasi dapat dilakukan oleh Kemenristekdikti dan AIPKIND terhadap proses pembelajaran dengan mengadakan Uji Tahap Bersama (UTB) minimal 2 kali selama pendidikan untuk mengetahui hasil pembelajaran. Pelaksanaan exit exam merupakan solusi yang harus segera direalisasikan untuk menjamin mutu dan kualitas lulusan pendidikan DIII kebidanan.

\section{Ucapan Terimakasih}

Terima kasih kami sampaikan kepada Kepala Pusat Penelitian dan Pengembangan Sumber Daya dan Pelayanan Kesehatan Badan Litbangkes dan Panitia Pembina Ilmiah (PPI) Pusat Penelitian dan Pengembangan Sumber Daya dan Pelayanan Kesehatan Badan Litbangkes yang telah memfasilitasi kajian ini, serta kepada semua pihak yang membantu terlaksananya kajian ini yang tidak dapat kami sebutkan satu persatu. Ucapan terima kasih juga kami sampaikan kepada Dra. Rini Sasanti
Handayani, Apt, M.Kes, Dr. dr. Harimat Hendarwan, M.Kes, dr. FX. Suharyanto Halim, MS, Sp.OK , Drs. Max Joseph Herman, Apt., M.Kes dan Dr. drg. Indirawati Tjahja Notohartojo, Sp.Perio yang telah memberi masukan selama kajian ini berlangsung.

\section{Daftar Rujukan}

1. Pemerintah Republik Indonesia. UndangUndang Republik Indonesia Nomor 36 Tahun 2014 Tentang Tenaga Kesehatan. 2014 [diakses pada tanggal 12 Agustus 2019]. p 3. Tersedia pada: https://ipkindonesia.or.id/media/2017/12/ UU-No.-36-Th-2014-ttg-Tenaga-Kesehatan.pdf

2. Rosita R, Hendarwan H, Despitasari M. Evaluasi penyelenggaraan pendidikan DIII kebidanan di 5 Provinsi wilayah binaan GAVI. J Penelit dan Pengemb Pelayanan Kesehat [Internet]. 2017 [diakses pada tanggal 12 September 2019];1(2):120-30. Tersedia pada: https://ejournal2.litbang.kemkes.go.id/index. php/jpppk/article/view/510/163. DOI: https:// doi.org/10.22435/jpppk.v1i2.510

3. Despitasari M. Laporan riset penyelenggaraan pendidikan tenaga kesehatan di Indonesia tahun 2017. Jakarta: Puslitbang Sumber Daya dan Pelayanan Kesehatan, Badan Penelitian dan Pengembangan Kesehatan, Kementerian Kesehatan RI. 2017.

4. Kementerian Riset, Teknologi dan Pendidikan Tinggi RI. Panduan Penyusunan Kurikulum Perguruan Tinggi. Jakarta: Direktorat Jenderal Pembelajan dan Kemahasiswaan [Internet]. 2016 [diakses pada tanggal 12 Oktober 2019]. Tersedia pada: https://ldikti12.ristekdikti. go.id/2016/08/27/edaran-dan-panduanpenyusunan-kurikulum-pendidikan-tinggitahun-2016.html

5. Kementerian Riset, Teknologi dan Pendidikan Tinggi RI. Peraturan Menteri Riset, Teknologi dan Pendidikan Tinggi no 44 tahun 2015 Tentang Standar Nasional Pendidikan Tinggi [Internet]. 2015 [diakses pada tanggal 12 November 2019]. p.58. Tersedia pada: https://lldikti12. ristekdikti.go.id/2016/01/15/permenristediktino-44-tahun-2015-tentang-standar-nasionalpendidikan-tinggi.html

6. http://ukbidan.ristekdikti.go.id/index.php/ pages/statistik_lulus 
7. Werni S., Rosita R., Prihartini N. DM. Laporan Kajian kebijakan program pendidikan DIII kebidanan berdasarkan hasil riset penyelenggaraan pendidikan tenaga kesehatan (Kesesuaian Permenristekdikti No.44 Tahun 2015, Permenkes No.97 Tahun 2014 dan Kepmenkes 369/MENKES/SK/III/2017). 2018;

8. Kementerian Kesehatan RI. Keputusan Menteri Kesehatan Republik Indonesia No 369/ MENKES/SK/III/2007 Tentang Standar Profesi Bidan [Internet\}. 2007 [diakses pada tanggal 13 November 2019]. p 10-22. Tersedia pada: http://www.pdpersi.co.id/peraturan/kepmenkes/ kmk3692007.pdf

9. Pemerintah Republik Indonesia. UndangUndang Republik Indonesia Nomor 4 Tahun 2019 Tentang Kebidanan. 2019 [diakses pada tanggal 16 September 2019]. p 3. Tersedia pada:https://jdih.bssn.go.id/wp-content/ uploads/2019/10/UU-Nomor-4-Tahun-2019.pdf

10. Kementerian Riset, Teknologi dan Pendidikan Tinggi RI. Surat Edaran Uji Kompetensi bagi calon lulusan pendidikan tinggi bidang kebidanan dan keperawatan. 2013 Jakarta: Direktorat Jenderal Pendidikan Tinggi [Internet]. 2013 [diakses pada tangal 17 Februari 2020]. Tersedia pada: http://www.kopertis12.or.id/ wp-content/uploads/2013/08/SE_DIRJEN_ DIKTI_704_-_UJI_KOMPETENSI_BIDAN_ DAN_PERAWAT.pdf

11. Fitria R, Serudji J, Evareny L. Persiapan uji kompetensi bidan sebagai exit exam. JIUBJ [Internet]. 2019 [diakses pada:tanggal 18 februari 2020];19(1):195-203. Tersedia pada: http://ji.unbari.ac.id/index.php/ilmiah/article/ view/590/524. DOI: 10.33087/jiubj.v19i1.590

12. Putriana Y. Kompetensi asuhan kebidanan komunitas berhubungan dengan kemampuan bidan melaksanakan perawatan kesehatan masyarakat pedesaan. $\mathrm{J}$ Stikes [Internet]. 2012 [diakses pada tanggal 16 November 2019];5(2):179-90. Tersedia pada: https:// media.neliti.com/media/publications/210241none.pdf.

13. Despitasari M, Rosita R. Hubungan kompetensi dan pelaksanaan wewenang bidan praktik mandiri di Kota Bogor Tahun 2013. J Ekol Kesehat [Internet]. 2015 [diakses pada tanggal 25 November 2019];14(2):171-80. Tersedia pada: https://media.neliti.com/media/ publications/81892-ID-hubungan-kompetensidan-pelaksanaan-wewe.pdf

14. Hutapea R. Determinan kinerja dan kompetensi bidan di Provinsi Sumatera Utara, Nusa Tenggara Timur, Kalimantan Barat, dan Sulawesi Selatan. Kesmas Natl Public Heal J [Internet]. 2011 [diakses pada 23 November 2019];6(1):29-34. Tersedia pada: http://journal. fkm.ui.ac.id/kesmas/article/view/116/117

15. Pusat Pendidikan dan Pelatihan Tenaga Kesehatan. Standar dosen pendidikan tinggi vokasi tenaga kesehatan. Jakarta: Badan PPSDM Kesehatan [Internet], 2013 [diakses pada tanggal 3 Desember 2019]. Tersedia pada: https://poltekkesdepkes-sby.ac.id/wp-content/ uploads/2015/05/19_Standar-Dosen-PTVokasi-Nakes-2013.pdf

16. Hadina H, Mangun M, Effendi JS, Susiarno H. Faktor diri mahasiswa yang memengaruhi kelulusan uji kompetensi D III kebidanan di Poltekkes Kemenkes Palu. J Ilmu Kesehat [Internet]. 2017 [diakses pada tanggal 5Desember 2019];1(22):1120-31. Tersedia pada: https:// www.google.com/search? safe $=$ strict\&sxs$\mathrm{rf}=\mathrm{ALeKk} 03$ ADmcUFKZI1S0QhoHmeG$\mathrm{N} 0 \mathrm{GdaA}-\mathrm{A}: 1589768054017 \& \mathrm{q}=\mathrm{Ha}-$ $\mathrm{da} \mathrm{in} \mathrm{a+dkk.+Faktor+Diri+Maha-}$ siswa + yang + Mempengaruhi + Kelulusan $+\mathrm{U}-$ $\mathrm{ji}+$ Kompetensi $+\mathrm{D}+\mathrm{III}+\mathrm{Kebidanan}+\mathrm{di}+\mathrm{Pol}-$ tekkes + Kemenkes + Palu. $+\mathrm{J}+\mathrm{Il}$ mu + Kesehat . $+2017 ; 1(22): 1120 \% \mathrm{E} 2 \% 80 \% 9331 . \&$ spell $=1 \& \mathrm{sa}=$ X\&ved=2ahUKEwi_5InBq7zpAhVYbn0KHbALD64QBSgAegQIChAn\&bi$\mathrm{w}=1304 \& \mathrm{bih}=648$ 